\title{
Nun will die Sonn' so hell aufgehn: Presence in absence
}

\author{
Jonathan Powles
}

One of the initial tasks in approaching this paper was to define the characteristics of the idea of 'lament' in somewhat structural terms. In fact, this goal of articulating 'lament' as a concept, as opposed to merely letting the multiple meanings of the word resonate as they will, was, for me, a persistent irritation. Or perhaps it was more like one of those occasions when one forgets a name, or a word, that then remains frustratingly, infuriatingly on the tip of one's tongue, because the tantalising idea that underpins the concept of 'lament' is surely one of absence.

Every lament is an encounter with an absence. The classic, canonic and central laments are the elegies and threnodies that mark the felt absences of death. But, life being what it is, there are many other subjects for lamentation: lament for lost love, lament for lost youth, all the way to Beethoven's rage over a lost penny, which certainly qualifies as a lament, even if an infantile one. And what has been frustrating me in my definitional musings is that I cannot think of one single example of a lament that does not encounter the lost, the absent - either actual or potential.

The nature of this encounter with absence varies by context. A musical ritual of mourning usually serves to place an individual's grief in a communal context: to share, and to locate mourning within a cultural tradition. In the lament as ritual, private grief is made public through communal enactment.

In contrast, an artistic response to absence usually creates a presence: through art, music, poetry or an image of what or whom is lost is created within the work. In the lament as art form, from a real or literal absence, a figurative presence is generated: an image of the departed. Here, private grief is made public through communicative representation.

The majority of my paper concerns the nature of this communicative representation in the first of Mahler's Kindertotenlieder: 'Songs on the Death of Children.' The notion of 'presence' is loaded, theoretically speaking, and is a contested one, and in some senses this short song of Mahler's is about to become the battleground on which the theoretical struggle for presence will be waged. But first I'd like to fling a few visual and textural laments into the mix, to provide some depth and perspective on the relationship between presence and absence. 


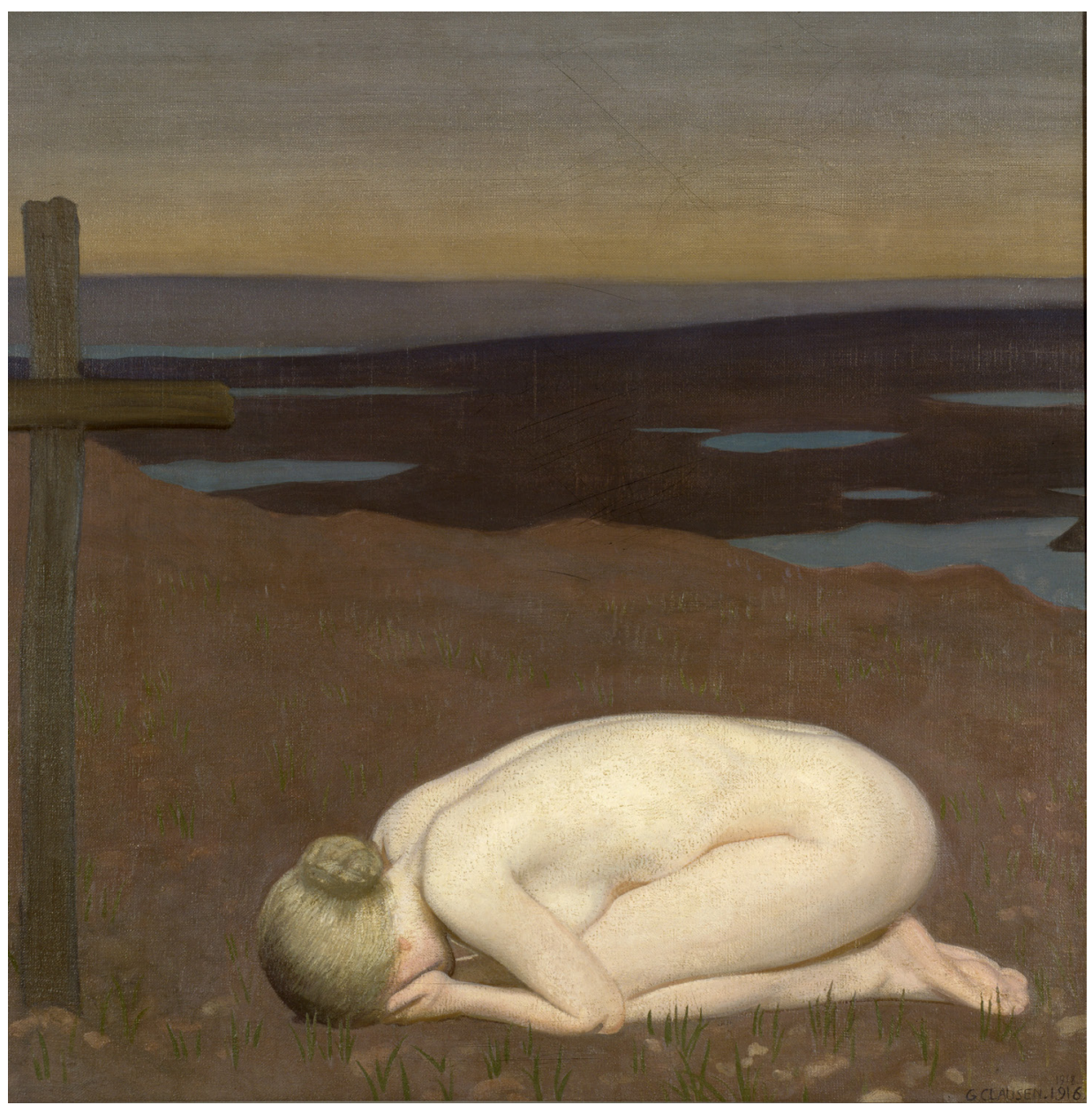

Figure 1 George Clausen, Youth Mourning, 1916

Source: Courtesy the author

Sir George Clausen painted Youth Mourning in 1916. Interpretation here is not problematic: the image is of youth, as a vulnerable, naked young woman, lamenting the dead young men of World War I. The kneeling figure in a ritual posture of grief, together with the partial cross, frames in the background the waterlogged shell-holes of a Flanders field. The interesting thing here is the portrayal of absence - in particular, the cross being truncated at the edge of the canvas tells us that the focus of the composition of the painting has been shifted to what is central, to what is even more important. The cross and the woman frame, enfold - cradle, if you will — what is at the centre of the painting. And what is central is... absent. A palpable absence. We could imagine the mourning 
woman as Isolde, singing to a dead Tristan who only she can see. It is not that there is nothing at the centre of the painting: on the contrary, there is something, gone. A presence through absence.

Rather than my waxing lyrical about this conceptual inseparability of absence and presence in the lament, it is probably better to let Shakespeare do so for me. Certainly Harold Bloom would approve of letting art speak in place of criticism. ${ }^{1}$ Shakespeare's 'Sonnet 64' is both a lament and a love song, and makes the point of presence in absence more compellingly than I could:

When I have seen by Time's fell hand defaced

The rich proud cost of outworn buried age;

When sometime lofty towers I see down-razed

And brass eternal slave to mortal rage;

When I have seen the hungry ocean gain

Advantage on the kingdom of the shore,

And the firm soil win of the watery main,

Increasing store with loss and loss with store;

When I have seen such interchange of state,

Or state itself confounded to decay;

Ruin hath taught me thus to ruminate,

That Time will come and take my love away.

This thought is as a death, which cannot choose

But weep to have that which it fears to lose.

'A thought... which cannot choose but weep to have that which it fears to lose' actually maps the absent onto the present by force-weeping in the presence of the beloved in the face of the inevitability of absence. There are two powerful presences in this sonnet: one is the speaker, invoking the personified force of time, ruin and destruction. The other is his beloved - but she is absent. She does not speak. Her presence is only affirmed, held, cradled, by the words describing her inevitable departure. There is, it seems, inhabiting the concept of the lament as artwork a structural pairing between presence and absence, in which the figure, the image of one gone, is enfolded or framed by what is present: the metaphor I have been using is that of 'cradling'.

This notion of cradling the lamented is useful in thinking about the first of Mahler's Kindertotenlieder. The original Kindertotenlieder were a group of 428 poems written by Friedrich Rückert in 1833-34 in reaction to the illness and death of his two children, Luise and Ernst. They were an essentially private

1 Bloom, Harold 1994, The Western Canon: The books and school of the ages, Harcourt Brace, New York. 
set of laments, not intended for publication and only published after Rückert's death in 1872. Mahler chose five of the poems for his setting, which he wrote between 1901 and 1904. I want to look in detail at the first.

Nun will die Sonn' so hell aufgehn,

Als sei kein Unglück die Nacht geschehn!

Das Unglück geschah nur mir allein!

Die Sonne, sie scheinet allgemein!

Du mußt nicht die Nacht in dir verschränken,

Mußt sie ins ew'ge Licht versenken!

Ein Lämplein verlosch in meinem Zelt!

Heil sei dem Freudenlicht der Welt!

Now the sun will rise as brightly

as if no misfortune had occurred in the night.

The misfortune has fallen on me alone.

The sun - it shines for everyone.

You must not keep the night inside you;

you must immerse it in eternal light.

A little light has been extinguished in my household;

Light of joy in the world, be welcome

Already we have several presences. Mahler's music enfolds and cradles the presence of the poet, himself gone, but allowed to speak through and with the music. And the poet inscribes a protagonist, the one who speaks and sings: a father who has lost his child in the night. Overwhelmingly, though, the most palpable presence in the song is the absent one: the dead child to whom the second stanza of the poem is (perhaps) addressed. Mahler's music cradles an image of the dead poet, whose poetic imagination enfolds an imagined grieving father, who speaks of, holds and cradles in words his absent child.

Now, at this point, as presences multiply alarmingly, it might be wise to invoke some theoretical and semiotic perspectives. The aim is to seek clarification, but the probable result will be no doubt to further complicate the issue. In a different domain - or possibly different - the battle between 'presence' and 'absence' is the central issue of theory and criticism of the late twentieth century. The deconstruction of what Derrida termed the 'illusory metaphysics of presence' is the first item on the post-structuralist agenda. ${ }^{2}$ For the criticism of literature and the arts, Derrida's assault on presence - simultaneous to and cognate with Barthes' declaration of the death of the author-had the effect of rendering

2 Derrida, Jacques 1967, De la grammatologie, Les Éditions de Minuit, Paris. 
impossible the idea of authorial presence in a work. ${ }^{3}$ Meaning is generated through the interplay of texts, the constellation of signs and codes brought together and to bear by the reader or listener in the act of interpretation. The very idea of authorial presence - the notion that Mahler, or Rückert, is speaking to us through the words and music, bringing a privileged and essential meaning to the work - is called into question by the inherent nature of language itself (and here, we treat music as a language) to subvert its own meanings; meaning is always partial, incomplete, deferred, provisional, in an endless cycle of intertextual interpenetration that Derrida terms difference.

This post-structuralist and deconstructive position is theoretically compelling; however, it does have its opponents: John Searle was Derrida's most famous sparring partner in the world of philosophy, but in literary criticism the key figure is perhaps Harold Bloom. Bloom's concept of artistic meaning is so centred in the notion of the artist wrestling with tradition, with the oedipal ghosts of his or her predecessors, that some notion of real authorial presence by necessity underpins his conception of meaning. Christopher Norris described it well when he wrote:

Bloom [seems] torn between a defence of poetry which holds to the ethos of Romantic individualism, and a deconstructive poetics which tends to dissolve such themes into an abstract system of tropes and relationships. In the last resort, however, Bloom is always willing to invoke the terminology of 'voice', 'presence' and subjective origin which Derrida so resolutely tracks down to its metaphors. ${ }^{4}$

Less well known than Bloom is George Steiner. Steiner's 1989 essay Real Presences - subtitled Is there anything in what we say? - acknowledges the theoretical unarguability of a deconstructive position, but takes issue with it on ethical rather than theoretical grounds. ${ }^{5}$ I shall return to Steiner's intriguing position at the end of my paper.

In the Mahler, we can see representational and intertextual signification at work in the song at the most obvious and accessible level of interpretation of musical meaning. This is at the level I would term mimetic semiosis: the music makes imitative reference to ideas in the text, or to ideas that are easily inferred from the context, through the invocation of a referential musical language, to the vocabulary and grammar of which each listener has different and provisional access.

3 Barthes, Roland 1978, Image-Music-Text, Hill and Wang, New York.

4 Norris, Christopher 1982, Deconstruction: Theory and practice, Routledge, London and New York.

5 Steiner, George 1991, Real Presences: Is there anything in what we say?, University of Chicago Press, Chicago. 
For instance, the repeated, paired couplets are a familiar musical figure, standing for, signifying 'sighing' and invoking musical texts from Dowland and Mozart to Wagner, for those able to understand the code. Second, the abrupt shifts of modality from major to minor evoke the shifts from light to dark in the poem, for listeners with even the most cursory familiarity with the affective references of Western music since 1500.

There are more specific intertextualities. The ascending chromaticism, descending diatonic minor vocal lines and tonic pedals all recall Schubert's Der Tod und das Mädchen - clearly a resonant and appropriate text for Mahler to evoke. There are other parallels with songs from the Schwannengesang cycleSchubert's last. Once the door of intertextuality is open, of course, many visitors come flooding in - for instance, Kofi Agawu has observed the presence in the music of the Kindertotenlieder of Brahms-like developing variation, and harmonic practice that echoes Wagner's Tristan. ${ }^{6}$

One aspect of mimetic semiosis that draws attention to itself is Mahler's use of the repeated glockenspiel strokes. This recalls the sound of bells tolled to announce a death: the eponymous 'death knell'. Sometimes the age of the deceased dictated the number of bell strokes - and here, there are two strokes.

Semiotically, these bells are doing more than making a mimetic imitation of funeral bells. They are, of course, small and high - child-sized tolling, if you will - and quite specifically echo the text 'Ein Lämplein verlosch in meinem Zelt!': a little lamp has gone out in my household. The little lamp is the soul of the child, and with these glockenspiel strokes Mahler offers an aural depiction of that childlike soul.

The graphic explicitness of this aural image of the soul is slightly trite. Indeed, it is possible to find it quite comic - although revealing that we do not do so. There is a visual analogy for this depiction that could be illuminating. I think what Mahler has done sonically is similar to what the director has done visually in the third Harry Potter film. There is an image of the soul leaving the body: a bright, white point of light - the visual analogue of Mahler's glockenspiel strokes. ${ }^{7}$ This is extreme mimesis - representation or metaphor driven to excess. It permits the most anachronistic intertextualities, between Mahler and Harry Potter, although I wouldn't go so far as to deny the aesthetic similarities between the two. It is also, in both cases, trite in the extreme.

So where does this leave us in terms of presence and absence in the lament? A surface-level investigation of semiosis, which highlights the intertextual

6 Agawu, V. Kofi 1983, 'The musical language of Kindertotenlieder No. 2', The Journal of Musicology, vol. 2, no. 1, pp. 81-93.

7 <http://harrypotter.wikia.com/wiki/Soul> 
interplay of mimetic reference, quickly confirms a post-structuralist reading of presence in the musical text. There is a shifting, provisional and partial presence of Rückert, Mahler, the imaginary father and child conveyed through bells, sighs and overtly referential musical symbolism. It's not that difficult to follow the chain of intertextuality to find the presence of Schubert, Brahms, Wagner... or indeed Harry Potter.

Indeed, perhaps because of this lack of interpretative difficulty, the entire deconstructionist project left music relatively untouched, compared with literature and philosophy. The notion that referentiality in music is provisional, deferred, partial and incomplete is not exactly earth shattering - as it proved for language - as the specific nature of referential signification of music has always been problematic. On the contrary, traditionally, the quest for musical presence, for authorial voice, has been located in the domain of structure, in the musical syntagm, rather than the musical vocabulary. The presence of the composer has been observed in ideas like the unity and organicism of the musical work as a demonstration of compositional vision, or through the conceptual superstructures afforded by syntactical tools such as the leitmotiv or dodecaphonic organisation.

Seeing the work's structure, rather than referents, as the site of meaning is what I shall term allegorical semiosis. This terminology follows that of poststructuralist Paul de Man, who sought to re-prioritise structure - the 'rhetoric of pure figuration' - over symbolic or referential modes of meaning. ${ }^{8}$ What happens when we look for meaning in the syntactical structure of music, without reference to possible mimetic, intertextual or extra-musical signification, but equally without reference to pre-ordained codes of musical structural interpretation: sonata forms, presuppositions of unity whether motivic or harmonic, as well as more recent a priori music-analytic symbologies such as gendered structures?

The results of this allegoric structural reading of the first of the Kindertotenlieder are significant. Structurally, the music is extremely predictable. There are two generative voice-leading principles at work. One is a classic Schenkerian descent from the fifth scale degree towards harmonic closure:

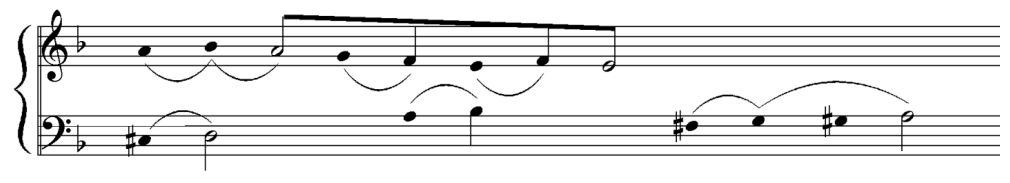

8 De Man, Paul 1983, Blindness and Insight: Essays in the rhetoric of contemporary criticism, Routledge, London and New York. 
But of course simple harmonic closure is never achieved. Rather, the upper voice resolves upwards by semitone (another 'sigh' in the mimetic plane). From this point of quasi-resolution then initiates the second generative voice-leading principle: a non-functional ascending linear chromatic motion that rises as high as the B-flat (the highest point, as an accented upper neighbour-note, of the original structural descent), at which point harmonic function kicks back in, the B-flat is reheard as a dominant minor ninth and the passage moves back towards the first principle of tonal resolution by stepwise descent.

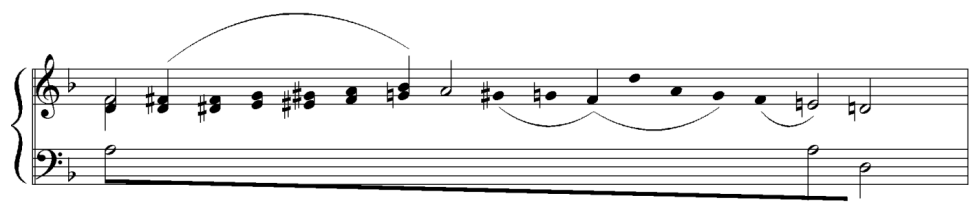

This gesture essentially happens the same way four times in the song: each time there is a moment of discontinuity, a point at which the upward chromatic linearity overpowers the gravitational pull of the functional harmony. This discontinuity is paralleled at the cadence points, in which linear chromatic motion arbitrarily intrudes and disrupts the goal-directed voice leading.

The point is this: there is absolutely no rational - musical - reason for the change of modality that precipitates the upward chromatic motion and its consequent emotional intensification. It is precipitated by a musical deus ex machina- a sudden and entirely logically inexplicable assertion of lightness or positivity. This abrupt move from darkness to light entirely parallels the structural unfolding of Rückert's text: 'The misfortune has fallen on me alone. The sun-it shines for everyone.'

Theoretically, there is an important distinction here. The music is not symbolising grief, or giving some metaphorical representation of grief. Rather, we are given in the actual structure of the music a play of figuration that is that of grief, in abstract: the chaotic and unpredictable shift from hope to despair that characterises the structure of mourning. This is where the fine distinction is to invoke the notion of allegorical semiosis - the rhetoric of pure figurationinstead of representative mimesis.

We are nearly at the end, and have explored some of the theoretical issues to do with the location of meaning in the first of the Kindertotenlieder. We have looked at mimetic semiosis, representation, intertextuality, allegorical meaning and musical structure as the sites of the communicative power of Mahler's music. I would wager, however, that we have been left unsatisfied - that none of these 
semiotic processes has adequately described what it is we understand from this music, and certainly none has captured the trope of presence in absence that seemed so intuitively compelling at the start of this paper.

In 'Real presences', George Steiner writes:

Face to face with the presence of offered meaning which we call a text (or a painting or a symphony), we seek to hear its language. As we would that of the elect stranger coming towards us. There is in this endeavour, as deconstruction would immediately point out, an ultimately unprovable hope and presupposition of sense, a presumption that intelligibility is conceivable and, indeed, realizable. Such a presupposition is always susceptible of refutation. The presence before us may be that of a mute (Beckett edges us towards that grim jest), of a madman uttering gibberish or, more disturbingly, of an intensely communicative persona whose idiom-linguistic, stylistic, hermetically-grounded-we simply cannot grasp. ${ }^{9}$

And here perhaps is the elephant in the room. This Mahler musical text comes towards us as a stranger, offering unprovable hope: that in this music, in these words, are cradled real presences, with whom we have genuinely transformative encounters - a grieving father, a lost child. The processes of signification are not, ultimately, what generate the most important meaning; it is ultimately ontological semiosis - the nature of being, the being-in-the-work, the presence and absence of real mourners.

What moves us, what makes the music profound, is that Mahler cradles in music Rückert's real and authentic grief. The grief is not yet Mahler's own; Mahler had lost no children when he composed the Kindertotenlieder. Sadly, he lost his fouryear-old daughter soon after completing the piece, and wrote: 'When I really lost my daughter, I could not have written these songs any more.' And maybe this comment should alert us to what is at stake.

Steiner argues that while the deconstructive position is theoretically irrefutable, ethically we need to make a wager on the real force of ontological semiosis, on the power of being-in-the-work to be a communicative force, and thus on the value of the arts to be a genuine tool with which to understand the human condition. Steiner particularly emphasises the role of music in this wager:

Music makes utterly substantive what I have sought to suggest of the real presence in meaning where that presence cannot be analytically shown or paraphrased. Music brings to our daily lives an immediate

9 Steiner, Real Presences, p. 151. 
encounter with a logic of sense other than that of reason. It is, precisely, the truest name we have for the logic at work in the springs of being that generate vital forms. ${ }^{10}$

And there I have to put to rest my own investigations into the semiosis at work in this little song of Mahler's. It feels like I have conjured up a theoretical maelstrom whirling around the still, calm centre of meaning in the song-which is the real, palpable presence of an absent child. And despite the luminous theoretical reputations of some of the spirits I have conjured-Jacques Derrida, Paul de Man, Harold Bloom, George Steiner-I might, in the end, leave the last words on the subject of the ontological question of the reality of presence to Harry Potter and Albus Dumbledore:

'Tell me one last thing,' said Harry. 'Is this real? Or has this been happening inside my head?'

Dumbledore beamed at him, and his voice sounded loud and strong in Harry's ears even though the bright mist was descending again, obscuring his figure.

'Of course it is happening inside your head, Harry, but why on earth should that mean that it is not real?' ${ }^{\prime 1}$ 